\title{
Emotive Meaning in Political Argumentation
}

\author{
FABRIZIO MACAGNO
}

\author{
ArgLab, IFILNOVA. Faculdade de Ciências Sociais e Humanas \\ Universidade Nova de Lisboa \\ Lisbon, Portugal \\ fabriziomacagno@hotmail.com
}

\section{DOUGLaS WALtoN}

Centre for Research in Reasoning, Argumentation and Rhetoric

University of Windsor

Windsor, Canada

dwalton@uwindsor.ca

\begin{abstract}
Donald Trump's speeches and messages are characterized by terms that are commonly referred to as "thick" or "emotive", meaning that they are characterized by a tendency to be used to generate emotive reactions. This paper investigates how emotive meaning is related to emotions, and how it is generated or manipulated. Emotive meaning is analyzed as an evaluative conclusion that results from inferences triggered by the use of a term, which can be represented and assessed using argumentation schemes. The evaluative inferences are regarded as part of the connotation of emotive words, which can be modified and stabilized by means of recontextualizations. The manipulative risks underlying the misuse and the redefinition of emotive words are accounted for in terms of presuppositions and implicit modifications of the interlocutors' commitments.
\end{abstract}

Résumé: Les discours et les messages de Trump sont caractérisés par des termes couramment appelés «affectif» et par une tendance à être utilisés pour générer des réactions affectives. Cet article étudie comment la signification affective est liée aux émotions et comment elle est produite ou manipulée. La signification affective est analysée comme une conclusion évaluative résultant d'inférences déclenchées par l'utilisation d'un terme, qui peut être représenté et évalué à l'aide de schémas d'argumentation. Les inférences évaluatives sont considérées comme faisant partie de la connotation des mots affectifs, qui peuvent être modifiés et stabilisés au moyen de recontextualisations. Les risques manipulatoires sous-jacents à l'utilisation incorrecte et à la redéfinition des mots affectifs sont comptabilisés en termes de présuppositions et de modifications implicites des engagements des interlocuteurs

Keywords: emotive language, slurs, pragmatics, argumentation schemes, connotation, rhetoric 


\section{Introduction}

The 2016 Presidential elections can be considered as unique. By rejecting the "politically correct" image of a presidential candidate, Trump adopted a type of rhetoric characterized by the frequent use of what has been reported by the press as "charged expressions" or "loaded language" (see, for instance, Stokols 2016; Wildermuth 2016; Gregoire 2016), which in the philosophical literature have been commonly referred to as "ethical" or emotive words (Stevenson 1937; Stevenson 1944). Words such as "losers" (Neuman 2015), "bimbo" (Gambino 2015), "stupid", "scum", "fools" are only the most stereotypical examples of terms that are not simply used to describe reality by modifying the cognitive response of the interlocutor (i.e., "informing" him), but more importantly to affect the interlocutor's attitudes towards a state of affairs and suggest a course of action. Ethical or emotive words are a powerful rhetorical instrument used for "framing" an issue (Druckman 2002; Entman 1993) and influencing the interlocutors' decisions. However, their nature and their effects constitute, also, crucial philosophical problems, involving philosophical positions, such as nominalism, contextualism, externalism, or inferentialism (Hom 2010), some of which have been debated over centuries. Such issues are recently attracting increasing attention from both a philosophical and linguistic perspective, even though most of the studies have focused on a specific type of emotive words, slurs (Croom 2011; Croom 2014; Blakemore 2015; Hom 2008; Hom 2010).

The importance and complexity of emotive words can be summarized in the following account given by Arnauld and Nicole in their Logic:

[...] people often do not consider the entire meaning of words. That is, words often signify more than they appear to, and when people try to explain their meaning, they do not represent the entire impression made in the mind. This is so because for an uttered or written sound to signify is nothing other than to prompt an idea connected to this sound in the mind by striking our ears or eyes. Now, frequently, in addition to the main idea which is considered its proper meaning, a word may prompt several other ideas - which may be called incidental ideas - without our realizing it, although the mind receives their impressions. For example, if we say to someone, "You 
lied about it," and we consider only the principal meaning of this expression, this is the same as saying: "You know that the contrary of what you say is true." But in common use these words carry an additional idea of contempt and outrage. They make us think that the person who says them does not care whether they injure us, and this makes the words insulting and offensive. (1996, chap. I, 14)

These reflections point to a controversial problem in pragmatics and philosophy, namely, the relationship between an utterance and its lexical components. While the speaker's communicative intention can be inferred only in the context of a conversation, it depends on the sentence meaning (Levinson 1983, pp. 16-19). Pejoratives, and more generally, emotive words shortcut the complex inferential relation between decoding and inferencing: they express the speaker's psychological attitudes towards the state of affairs referred to, and this effect is relatively stable in different contexts (Bianchi 2018; Hom 2010).

While pragmatic and philosophical theories have focused on the theoretical problem of explaining the nature of such effects, the representation of the emotive meaning, its relationship to emotions, and the possibility of modifying it have been almost neglected. This paper intends to account for the effects of emotive words in terms of inferences that can be represented as micro-arguments. Through some examples drawn from Trump's speeches and messages, this approach will be shown to objectify the vague notion of "emotive meaning" and allow the assessment of the use of such words, explaining the strategies and mechanisms used for crafting and triggering the "incidental ideas" and the associated emotive effects.

\section{Using loaded words}

The notion of "incidental ideas" clearly explains what has been referred to in the philosophical literature as "derogatory content" or "properties" (Hom 2010; Hom 2008) or "emotive meaning" (Stevenson 1937). The latter term, in particular, captures the essential connection between the properties of some terms (such as "peace", "democracy", or "terrorism") and emotions, or rather action-oriented, immediate responses. As Stevenson (1937, pp. 18-19) put it, "instead of merely describing people's interests, they change and intensify 
them. They recommend an interest in an object, rather than state that the interest already exists." Such terms have the tendency to lead the hearer towards a decision by affecting his or her system of interests (Stevenson 1944; Stevenson 1938a; Stevenson 1938b) because they can be used to elicit emotive reactions (Stevenson 1944, p. 54). This dimension of a word tendency, which is frequently dependent on the evaluation of the denoted state of affairs (for example, in cases such as "peace"), but can be independent from it (such as in "cur" vs. "dog") ${ }^{1}$, was called "emotive meaning". Words characterized by an emotive meaning can be used for persuading the interlocutor or the audience to carry out a specific action. More specifically, such terms (called "ethical" —or commonly referred to as emotive words) are characterized by the "wedding" between their descriptive and emotive meaning (Stevenson 1944, pp. 206, 210), as they at the same time describe a state of affairs and direct the interlocutor's interests towards their referent. For this reason, the speaker can manipulate or redirect the interlocutor's attitude (i.e., evaluation or interests) towards a state of affairs (in cognitive approaches to emotions, a "target", see De Sousa 1987, p. 20) by redefining the "descriptive meaning" or the "emotive meaning" of the ethical word used to refer to it (Stevenson 1938a, p. 332). In the first case, the ethical term is "persuasively defined", in the second case, "quasi-defined". The Trump campaign offers clear and philosophically relevant examples of these tactics, starting from the basic one consisting in the use of "emotive words".

\subsection{Using emotive words to craft emotions}

The most prototypical example of use of emotive words to steer the audience's emotions and evaluation of a state of affairs consists in the use of slurs. For example, we consider the following excerpt from Trump's campaign rally in Hilton Head Island, South Carolina (Federal News Service 2016), in which he describes journalists:

\footnotetext{
${ }^{1}$ This distinction is a distinction between "emotive meaning", which is the potentiality of a word, and the cause thereof, which can be usually found in the values associated with the denotation (the "ethical" dimension), but not necessarily.
} 


\section{Case 1: Scum and other slurs}

They're scum. They're horrible people. They are so illegitimate.... Some of the people in the press are honorable. But you've got $50 \%$ who are terrible people. [...]

I would never kill them, but I do hate them. And some of them are such lying, disgusting people. It's true. (Hampson 2016)

In particular, "scum" is a lexicalized metaphor, a slur whose definition includes an evaluation of the subject matter (very bad or immoral person) (Hom 2008). Other adjectives ("horrible", "terrible", "disgusting") are purely evaluative, namely provide an assessment of the name modified, which is described referring to the emotion that is encouraged (fear, unpleasantness, disgust). Finally, words such as "illegitimate" or "lying" can be considered as properly ethical words. They refer to a state of affairs commonly evaluated negatively, which thus has the "potentiality" of triggering - in certain contexts of use-a specific emotion (such as contempt). The evaluative component is not part of their definition but culturally associated with the referent.

In the example above, notice that the emotive meaning can be associated with a term in different fashions. Apart from slurs, some of which at least carry an evaluative component in their definition, and evaluative adjectives, Trump uses metaphors and "ethical" words. Metaphors, in particular, carry with them the common ground commonly associated with the vehicle (Kovecses 2015, pp. 179-180; Clark 1996; Ritchie 2006, pp. 88-96), namely, the frame or the script (Samet and Schank 1984) that is activated, or the context in which it has been previously or prototypically used (Ritchie 2006, pp. 190191; Kovecses 2015, pp. 180-181; Clark 1996, pp. 38-41). In this sense, such previous contexts make specific, accidental (evaluative) properties or inferences salient, i.e., accessible because of their conventionality, frequency, familiarity, or prototypicality (Giora 2008; Giora 2003, p. 147). For this reason, a metaphor can lead to associations and inferences that can trigger emotions, as pointed out in the Logic of Port Royal:

For in addition to their principal meaning, metaphors signify the speaker's emotion and passion, and thus imprint both ideas in the 
mind, whereas plain expressions indicate only the unvarnished truth. (Arnauld and Nicole 1996, chap. I, 13)

A clear example of the use of metaphors for arousing emotions can be found in the aforementioned speech given by Trump in South Carolina:

\section{Case 2: Behemoth}

I order thousands of televisions, they're all from South Korea. So we have 28,000 people on the border separating South Korea from this maniac in North Korea, we get nothing. What do - we get nothing. They're making a fortune. It's an economic behemoth. [...]

A lot of you don't know we protect Germany. Germany! Mercedes Benz, how many people have a Mercedes Benz? We protect Germany. It's an economic behemoth. (Federal News Service 2016)

Here, "behemoth" is used not only for referring to Germany or South Korea using the image of the biblical mighty beast. More importantly, the common ground associated with the vehicle due to the previous narrations (monster provoking chaos; monster destroying and eating the world) leads to negative assessments of the targets, leading to immediate emotional responses (danger, ergo fear).

A similar strategy is used for eliciting the emotive response of anger (Ben-Ze'ev 2000, p. 380) by depicting a state of affairs as an undeserved offence. Trump describes the United States as a "dumping ground" in which the world is depositing their garbage, i.e., the migrants:

\section{Case 3: Dumping ground}

And we're like a dumping ground for the world. We're a dumping ground. They want to take these migrants - the migrants, you know, and I feel terrible about the migration, caused by Hillary Clinton and Barack Obama. They're the ones that caused it. They go into Libya. They knocked the hell out of Gadhafi. OK, so Gadhafi they backed rebels who end up killing the ambassador and the other young people. (Federal News Service 2016)

In addition to implicitly labelling the migrants as "garbage", provoking the evaluation of inferiority which is the basis of contempt (BenZe'ev 2000, p. 390), Trump presents the problem of migration as an offence of littering the property of the Americans. These emotive 
words are then connected with the offenders (Obama and Clinton) who can thus become the objects of anger.

In addition to metaphors, similes can trigger similar emotive effects. In the following case, Trump emotionally describes his Republican competitor, Marco Rubio, as "weak like a baby". The word "baby" has no negative emotive meaning; however, Trump uses it to reinforce the evaluation of the opponent as weak, relying on the concept of helplessness usually associated with a baby. This simile, however, presents Rubio as a helpless baby, which is in striking contrast with the position he is aiming at, resulting in contempt and ridicule:

\section{Case 4: Baby}

Nice person, weak on illegal immigration ... like, weak like a baby. Like a baby. Not a good poker player, because every time he's under pressure he just starts to profusely sweat. If he was playing poker with me, I'd say 'Ah!' The water would start pouring off his body. (Hartmann 2016)

As Trump's vocabulary shows, emotive words are an umbrella term covering various types of associations between "descriptive" and "emotive" meaning, such as slurs (involving an evaluative component in their descriptive meaning), evaluative adjectives, ethical terms, and metaphors. What is common to all of such strategies is that the emotive meaning is prototypically associated with the word used, or (such as in case of "baby") is selected and clearly indicated contextually among the various evaluations commonly connected with the vehicle.

\subsection{Persuasive definitions}

The "wedding" between descriptive and emotive meaning of emotive words leads to a dangerous possibility, namely, the use of an emotive word to refer to a state of affairs that is normally assessed neutrally or even in a way different from the emotive meaning of the term used. In the Port Royal Logic, this strategy was described as follows:

As a result, the same thing can be expressed decently by one sound and indecently by another, if one of these sounds is connected to some other idea that conceals the shame, and if the other, by contrast, 
presents it to the mind in an immodest manner. Hence the words "adultery," "incest," and "abominable sin" are not shameful, although they represent extremely shameful actions, because they only represent them as covered by a veil of horror which causes them to be viewed simply as crimes. These words thereby signify the crime of these actions more than the actions themselves. On the other hand, certain words express these actions without the sense of horror, as being somewhat pleasant rather than criminal, and even join to them an idea of immodesty and effrontery. These are the shameful and indecent words. (Arnauld and Nicole 1996, chap. I, 13)

Here, emotive words are claimed to be used for referring to actions that are normally considered as offences or as shameful. The use of such words suggests or invites an evaluation that is different from the prototypical one, or that at least is not shared or commonly accepted. This possibility is rooted in the redefinition of the emotive word, i.e., in the strategy that Stevenson named persuasive definition (Stevenson 1938a; Macagno and Walton 2008; Macagno and Walton 2010). Persuasive definitions are explicit or implicit redefinitions of ethical words, aimed at redirecting their emotive meanings to states of affairs that would not be normally denoted by them. For example, by redefining "culture" as originality, the speaker can change the hearer's "interests by changing names", redirecting the interlocutor's evaluation of their referents and his related affect (Stevenson 1938a, p. 332; Macagno and Walton 2014, chap. 3). In this sense, persuasive definitions introduce ambiguity, as the speaker uses a term with a new meaning, while the hearer interprets the utterance in which it is used relying on its ordinary or presumptive meaning - and considering its presumptive preconditions and/or the prototypical contexts in which it normally occurs.

Trump uses this strategy very clearly in his aforementioned Hilton Head Island speech, where he uses the term "genius", a term normally associated with a very positive evaluation of the referent:

\section{Case 5: Genius}

No, no, no. They're fed up. They're fed up with the media. I mean, I've got - and you know, not all bad, but there's so much dishonesty in the media. And I like to call it out. And one of the things that's really been amazing to me, and such - it's been so beautiful to watch - the level of genius in the public. They get it, you know? 
They really get it. They want to marginalize us, they want to do all of this and they want to make everybody look like, "Oh, gee." The level of genius - they fully understand. They know they're crooked, they know they're dishonest and they really-otherwise, who gets worse publicity than me? (Federal News Service 2016)

Trump uses "genius", which by definition means "very great and rare natural ability or skill, especially in a particular area such as science or art", to refer to a very ordinary capacity, namely understanding an alleged discrepancy between real and reported facts. This tactic is used for other terms, such as "incredible" ("the incredible men and women of the United States military"), which are used for transferring the positive judgment - and the related emotion of admiration - from individuals and events "too extraordinary and improbable to be believed" to average people and actions. The ambiguity generated can also alter the presuppositions shared by the public, who can be led into accepting common capacities and workers as exceptional (Kecskes and Zhang 2013).

\subsection{Redefining emotive meaning}

A different strategy described by Stevenson is the quasi-definition, through which the speaker can modify the emotive meaning commonly associated with an expression. Through the repeated use of a term in a context that associates it with a positive or negative conclusion (Jeshion 2013), it is possible to introduce or modify its disposition to elicit a specific emotional response. A clear example is the modification and stabilization of the emotive meaning of "politically correct" in Trump's campaign.

"Politically correct" is not commonly perceived as necessarily derogatory (Bump 2015). However, in his campaign, Trump used this expression in contexts that were all characterized by a negative attitude towards its referent, which was justified based on specific suggested inferences. Political correctness was identified by Trump as a problem during the first Republican debate in August in the following reply to the attack by the moderator concerning some offensive comments about women that Trump had made: 


\section{Case 6: Politically correct}

I think the big problem this country has is being politically correct [...] I've been challenged by so many people, and I don't frankly have time for total political correctness. And to be honest with you, this country doesn't have time either. This country is in big trouble. We don't win anymore. We lose to China. We lose to Mexico both in trade and at the border. We lose to everybody. (Tumulty and Johnson 2016)

In this context, "to be politically correct" is characterized as a problem and contrasted with serious occupations ("I don't have time") and more importantly with addressing national interests and solving big troubles ("this country doesn't have time either"). Trump quasidefines this expression as a non-serious waste of time, a distraction from facing real problems, which characterises a group to which he, the non-politically correct one, does not belong at all. In other contexts, both in public speeches and on Twitter (@ realDonaldTrump 2015), "politically correct" was associated with the similar concepts (incidental ideas according to the Logic of Port Royal) of hypocrisy, foolishness, time-wasting, and cowardice.

\section{The rationality of emotive meaning}

As Stevenson pointed out, by using words that have (or have been given) the tendency to elicit an emotive response, it is possible to redirect "interests" or rather the evaluations of a state of affairs and the related decisions or judgments. This passage from the use of a word to the disposition to act in a specific fashion can be represented theoretically as a chain of inferential steps, allowing a critical evaluation of the reasonableness of a choice or a judgment. However, the abstract argumentative model cannot account for the effectiveness of emotive words. In order to investigate this dimension, we need to inquire into the heuristic reasoning steps that characterize the "emotive" dimension of the "loaded" or ethical words.

\subsection{The rationality of emotive words}

The "descriptive" and "emotive" meaning of ethical (or loaded, or emotive) words, i.e., the tendency to elicit cognitive or emotive 
responses, can be interpreted from a logical ${ }^{2}$ perspective as different types of inferences. The descriptive meaning can be regarded as an inference or a set of inferences attributing a predicate to an entity (a subject) based on specific characteristics and definitional premises (the process of "naming" reality). The emotive meaning can be interpreted as an inference (or as set of inferences) leading from a description of a state of affairs to a value judgment thereon (evaluation), and in some cases the proposal of a commitment to a course of action (decision-making inferences).

The descriptive meaning can be represented as an inferential passage (described as argumentative loci or topoi in the dialectical tradition) aimed at classifying a state of affairs. This inference is grounded on classificatory premises, which can be very different in kind. A classification (the attribution of a property to a subject/entity based on some properties characterizing it) can be grounded on definitions, descriptions, or stereotypes. Depending on the nature of the "definitional" premise, the acceptability and defeasibility of the conclusion vary. This inference can be represented using the following scheme (Walton, Reed and Macagno 2008, p. 319):

\section{Argumentation scheme 1: Argument from classification}

\begin{tabular}{|l|l|}
\hline Premise 1 & $\begin{array}{l}\text { If some particular thing } a \text { can be classified as } \\
\text { falling under verbal category } C, \text { then } a \text { has } \\
\text { property } P \text { (in virtue of such a classification). }\end{array}$ \\
\hline Premise 2 & $\begin{array}{l}a \text { can be classified as falling under verbal cat- } \\
\text { egory } C .\end{array}$ \\
\hline Conclusion & $a$ has property $P$. \\
\hline
\end{tabular}

The reasonable and correct application of this scheme can be assessed dialogically by taking into account its defeasibility conditions, represented by the following critical questions:

\footnotetext{
2 The term "logical" shall be considered as referring to the natural language logic investigated in the dialectical tradition and in argumentation theory.
} 
CQ1: What evidence is there that $a$ has property $C$, as opposed to evidence indicating room for doubt about whether it should be so classified?

CQ2: Is the classification premise the definition of $P$ ? Or is it merely a description thereof? Or is it a stereotype reporting only on a shared and unproven relationship between the two properties?

This scheme underlies both the use of an emotive word and the possible inferences that can be drawn from it (Macagno and Walton 2014, chap. 3). For example, the claim that "Clinton (or another opponent) is politically correct" can be acceptable because of a reason linking "politically correct" to a specific behavior of Clinton, such as refraining from attacking minorities or religious groups, namely, "avoiding language and practices which could offend political sensibilities". The link between her behavior and her classification is based on the definition of "politically correct", which can be hardly challenged. However, if this classification were based on the premise that "politically correct people are those who do not speak their mind (or are not concerned with real problems)" (namely, a mere description and not a definition), it would be much more defeasible. This type of reasoning can be used, also, for drawing further properties from a classification. For example, from the definitional premise it is possible to conclude that "Clinton does not want to offend people"; from the second descriptive premise, it is possible to infer that "Clinton does not speak her mind (or is not concerned with real problems)."

The classification scheme is one of the grounds of evaluative inferences, namely reasoning steps leading to a specific type of predication, consisting in the attribution of an evaluative predicate (the species of good and evil, Aristotle Topics, 123b9) based on specific topics:

First, then, that which is more lasting or secure is more desirable than that which is less so; and so is that which is more likely to be chosen by the prudent or by the good man or by the right law, or by men who are good in any particular line, when they make their choice as such; i.e. either whatever most of them or what all of them would choose; e.g. in medicine (or in carpentry) those things are more desirable which most, or all, doctors would choose; or, in 
general, whatever most men or all men or all things would choose, e.g. the good; for everything aims at the good. (Aristotle Topics, 116a13-116a21)

These types of evaluative premises are culture-dependent reasons for classifying something as desirable or not (Perelman and OlbrechtsTyteca 1951), and - just like other types of classifications - can be grounded on the definitions of evaluative predicates (what is good, desirable, dangerous, etc. see Vendler 1963; von Wright 1963) or stereotypes, and thus be more or less defeasible. For example, "politically correct" can be judged as desirable and good, as it is the privation of something evil, offending (provoking pain). Otherwise, it can be considered as evil, as politically correct people are hypocrites, and hypocrisy is falsity - an evil thing.

The difference between the descriptive and the emotive meaning of ethical (emotive) words thus consists in the different premises used for drawing further inferences from a classification of a state of affairs or an entity. Moreover, in both cases the conclusions (descriptive or evaluative judgments) may be grounded on more or less defeasible premises, depending on whether they are definitional (semantic) or mere stereotypes.

\subsection{The dynamic uses of emotive words}

Value judgments can be the premises of further action-oriented inferences, which can account for the "dynamic uses" of emotive words, namely, "inciting people to action" or venting emotions (Stevenson 1937, pp. 21-22). In both cases, the dynamic uses are aimed at altering people's attitude (affection), either by encouraging the hearer to commit himself to a course of action or behavior, or arousing sympathy (Ben-Ze'ev 2000, chap. 11). In particular, the actionoriented effect can be represented in terms of inferences, which can lead to a commitment (an attitude of the individual towards a judgment or a state of affairs, see Hamblin 1970; Walton and Krabbe 1995) or in more complex patterns, leading to further inferences.

The passage from a value judgment to a specific commitment can be represented as follows (Walton, Reed and Macagno 2008, p. 321) 


\section{Argumentation scheme 2: Argument from Values}

\begin{tabular}{|l|l|}
\hline Premise 1 & $\begin{array}{l}\text { The state of affairs } x \text { is positive/negative as } \\
\text { judged by Agent } A \text { according to Value } V \\
\text { (value judgment). }\end{array}$ \\
\hline Premise 2 & $\begin{array}{l}\text { The fact that } x \text { is positive/negative affects the } \\
\text { interpretation and therefore the evaluation of } \\
\text { goal } G \text { of Agent } A \text { (If } x \text { is good, it supports } \\
\text { commitment to } G \text { ). }\end{array}$ \\
\hline Conclusion & $\begin{array}{l}\text { The evaluation of } x \text { according to Value } V \text { is a } \\
\text { reason for retaining/retracting commitment to } \\
G .\end{array}$ \\
\hline
\end{tabular}

The object of the commitment is generically represented as a goal, which includes both a generic end towards which an action can be directed (approval or disapproval) or a specific one (supporting a candidate or voting against him). For example, the use of the term "politically correct" for describing Clinton's behavior can be normally considered as a reason for approving of her, or at least of her behavior. However, when Trump quasi-defined it, this phrase became an instrument for disapproving of her (and the Obama administration's) conduct, as hypocrisy (or frivolousness) that should be normally avoided, not trusted, or be disapproved of. The implicitness of the quasi-defined emotive meaning, however, leaves the conclusion of the inference vague, pointing at a generic zone of affect (positive or negative) rather than a specific emotion (Caffi and Janney 1994, pp. 327-328).

This generic commitment can become more specific by drawing the possible actions that can be used to pursue the goal of the agent. Practical reasoning and reasoning from consequences (von Wright 1963b; Macagno and Walton 2018) can be represented as schemes of inference connecting a desired situation - or rather a "declaration of intention", a commitment to bringing about a state of affairswith conditions. In the first case, the agent can reason by selecting (committing to) the productive or necessary means for bringing about the desired state of affairs (the best way of disapproving of Clinton is not to vote for her). In the other type of reasoning, called argument from consequences, the agent only considers one 
relationship between a desirable or undesirable state of affairs and the action that is the necessary or productive cause thereof. This inference can be represented as follows (Walton, Reed and Macagno 2008, pp. 332-333):

\section{Argumentation scheme 3: Argument from consequences}

\begin{tabular}{|l|l|}
\hline Premise 1 & $\begin{array}{l}\text { If action } Q \text { is brought about, good (bad) con- } \\
\text { sequences will plausibly occur. }\end{array}$ \\
\hline Premise 2 & $\begin{array}{l}\text { Good (bad) consequences are (not) desirable } \\
\text { (should (not) occur). }\end{array}$ \\
\hline Conclusion & Therefore, $Q$ should (not) be brought about. \\
\hline
\end{tabular}

For example, this type of reasoning underlies the passage from the negative evaluation of a "politically correct" candidate or her possible future actions (a politically correct president is not desirable; the politically correct behavior of a president is not desirable) to a specific action (I should not vote for her).

This type of analysis can represent the possible inferences that emotive words trigger. However, it does not take into account the other dimension of emotive meaning, namely, the impact of a (potential) emotive reaction to the use of emotive words in emotive utterances. This effect can explain the rhetorical effectiveness of such words, accounting for a faster, heuristic, and not critically assessed connection between a classification and a commitment.

\section{The fast rationality of emotive words}

One of the first accounts of the relationship between emotions, value judgments, and heuristic reasoning can be found in the aforementioned Logic of Port Royal. The authors noted that the connection between some "ideas" and their evaluation is automatic and is grounded on past emotional responses:

The first and main inclination of lust is towards the sensual pleasure that arises from certain external objects. Aware that the pleasure it adores is derived from these things, the soul immediately connects them with the idea of good, and whatever deprives it of pleasure with the idea of evil. Next, seeing that riches and human power are the 
usual means for mastering these objects of human lust, the soul begins to regard them as a great good. Now since there is a certain excellence in happiness, the soul never separates these two ideas, always regarding everyone it considers happy as great, and those it considers poor and unhappy as lowly. (Arnauld and Nicole 1996, chap. I, 9)

This passage summarizes the logic of emotions, or more precisely, the heuristic mechanisms underlying the uses of emotive words. The starting point is the conceptual dimension of emotions developed in the cognitive theories of emotions (Elster 1999, chap. 4; Pugmire 1998; de Sousa 1987; Ben-Ze'ev 2000). On this view, emotions presuppose specific subjective evaluative judgments (Solomon 2003): to feel an emotion corresponds to implicitly appraising a situation. The evaluative judgment (determining "whether an event is good or bad and whether people's current actions and environment correspond to their personal goals and expectations" (Keltner and Lerner 2010, p. 315)) is connected with cognition (Lerner et al. 2015) and can be modified by means of arguments (Elster 1999, p. 56). The appraisal of a state of affairs provides a reason for a physical and psychical reaction that can drive us to action (Frijda and Mesquita 2000, p. 46), or rather a tendency to perform a type of action (fleeing, reducing uncertainty, etc.).

The appraisal aspect of emotions is strictly culturally dependent, as the values (including morals, ethical norms, aesthetic criteria, etc.) are not only the result of personal past experiences (Damasio 1994, p. 246), but more importantly of culture, which embodies a community's experiences (Smith and Lazarus 1990, p. 627; Frijda and Mesquita 1998; Frijda and Mesquita 2000; Solomon 2003, p. 87). Since emotions involve value judgments, and value judgments can be triggered, suggested, or advanced by the use of emotive words, emotions can be crafted rhetorically. This relationship between words and emotions, which is the ground of Aristotle's Rhetoric, is twofold. Emotive words can suggest, or rather heuristically trigger, a value judgment, a presupposition of emotions; in turn, emotions have an epistemic effect, altering our perception of the described events. Emotive words can evoke or depict scenarios that we can imagine and confront with our memories (Frijda 1988; Elster 1999), and at the same time can make us experience a specific emotion. In 
this fashion, the description becomes a "vivid illustration" (Quintilianus Institutio Oratoria, VIII, 3, 61) that we can perceive as real through our senses (Frijda and Mesquita 2000, p. 69; Clore and Gasper 2000, p. 26). The use of emotive words thus can arouse artificial emotions and instill beliefs.

Emotive words can trigger emotional responses, which are, from a reasoning point of view, shortcuts of the more complex inferential and critical mechanism described in the previous section. Emotional judgments are hasty and biased, leading to automatic conclusions of right and wrong (Damasio 1994; Greene and Haidt 2002; Keltner and Lerner 2010, p. 331), which in turn are at the basis of a sudden action tendency (depending on the intensity of the emotion), automatic, time-tested responses, requiring low processing efforts (Loewenstein and Lerner 2003, p. 628). Emotive words thus provide or suggest an evaluation that activates a pattern of automatic (heuristic) reasoning (Chen and Chaiken 1999; Kahneman 2003; Petty and Cacioppo 1986), which has devastating effects on the critical (systematic) assessment of the described or referred-to state of affairs (Loewenstein and Lerner 2003; Blanchette and Richards 2004).

On this perspective, the use of ethical words such as "liars", "dumping ground", "bimbo", or "behemoth" mirror the interlocutor's previous experiences creating a relationship between them and the case at issue that can trigger an immediate emotive response or a decision. These negative associations, resulting from memories or previous contexts evoking emotional reactions (Doerksen and Shimamura 2001), provide the hearer with a shortcut to a conclusion that inhibits the systematic assessment of the variables and critical aspects involved in the inferential steps mentioned above. A liar is not only a person not telling the truth; he or she is a contemptible individual. A dumping ground is not a metaphor for a place hosting allegedly unwanted people; it a place that has become shameful because of others. Emotive words suggest emotions by means of associations and memories, and in turn emotions lead to immediate conclusions concerning the assessment of a state of affairs and the related agent's commitments. The hearer is led to feeling emotions such as contempt for journalists and anger against those who turned America into a shameful place, which influence his possible intentions to act. 


\section{Crafting heuristics: Connotation and emotive meaning}

In Sections 1 and 2 above, we noticed how emotive words can be used for eliciting an "affective" (using Stevenson's terminology) or, rather, emotional, response, and how the "tendency" to be used for this purpose that characterizes such words can be modified. In particular, we pointed out how Trump in his speeches alters the "emotive meaning" of the otherwise neutral or positively evaluated concept of "politically correct". However, he changes the prototypical context in which it is used, thus associating the phrase with different and negative "incidental ideas", such as hypocrisy, falsity, or weakness. Trump focuses his strategy on the commonly shared connection between "politically correct" and what in Port Royal Logic was called "incidental ideas":

But sometimes these incidental ideas are connected to the words themselves, because they are normally prompted by everyone who utters them. This is why, among expressions that appear to mean the same thing, some are insulting and others are polite, some are modest and others immodest, some decent and others indecent. Because in addition to the principal idea which they share, people have connected them to other ideas which cause this diversity. (Arnauld and Nicole 1996, chaps. I, 14)

This excerpt points out two important aspects of emotive words. First, Arnauld and Nicole distinguished between two dimensions of the "comprehension" of a term, i.e., the "traits that define its content": the denotation (namely, the definitional features used for classification or referential purposes) and the connotation (namely, the additional sematic features) (Kerbrat-Orecchioni 1977, p. 12). Second, they pointed out how the ordinary use affects such additional semantic features.

The "emotive meaning" of ethical words can be investigated in terms of connotation. We can divide the broader category of "emotive words" in two categories: terms (such as some slurs, such as "bimbo" or derogatory adjectives such as "weak" or "stupid") that include in their definition an evaluative component, and terms (such as all the words that Stevenson analyzes under the proper label of "ethical" terms, representing the majority of our examples) whose evaluative component is only an accessory and not a definitional 
feature. In this latter case, this connotative meaning can be considered as resulting from the uses of the term, acquiring an additional meaning triggered not directly by its relationship with its definitional features (and the referent), but as a sign used within a linguistic system or a context. Connotation can be represented as a distinct, but not independent, level of meaning of a sign, using the terminology of Hjelmslev (1969; Molino 1971; Kerbrat-Orecchioni 1977):

\begin{tabular}{|l|l|l|}
\hline \multicolumn{2}{|c|}{ Expression (sign) } & Content \\
\hline Expression & Content & \\
& &
\end{tabular}

Level of

Connotation

Level of

Denotation

\section{Figure 1: Representing connotation}

As Kerbrat-Orecchioni pointed out, the sources of the connotative meaning can be different. She distinguishes five categories of connotations, including: "utterance" connotations; stylistic connotations; phonetic, rhythmic, syntactic connotations; associated values; implicit/semantic values (information on the referent) (KerbratOrecchioni 1977, p. 167). In particular, utterance connotations ("connotations énonciatives") include the semantic features that characterize emotive meaning, namely ideological, axiological (value judgment) and emotive connotations, which can convey value judgments that can trigger emotional responses (Cato et al. 2004). These non-definitional features can be the result of the use of a term in a specific utterance to pursue a specific purpose, such as the aforementioned use of the phrase "politically correct" by Trump (Case 6). However, this speech meaning can become integrated at a cultural level (Garza-Cuarón 1991, pp. 213-214). The context can become culturally associated with the use of a specific term, which acquires a more stable connotative meaning (Kerbrat-Orecchioni 1977, p. 119). In a sense, the lexical items thus "encapsulate" prior contexts of experience: "they carry context (prior context), encoding the history of their prior use (prior context) in a speech community" 
(Kecskes 2013; Kecskes 2008; Kecskes and Zhang 2009). As Kecskes put it (2013, p. 133):

Lexical items encode the history of their use, which basically creates a record of prior contexts. They trigger frames and cultural models that the interlocutor has experienced before. [...] Linguistic units encapsulate the history of their use, i.e., the situations in which they have been used (Kecskes 2008). What happens in communication is that prior context encoded in the utterances interplays with the actual situational context, and this interplay results in what we call "meaning."

In particular, Kecskes points out a dimension of meaning (which involves "word-specific elements" and "culture-specific conceptual properties"; see Cruse 1992; Kecskes 2003, pp. 40-43) distinct from the semantic (definitional, or better conceptual) one. We can draw a correspondence between the first dimension (including both lexicalized and cultural properties of a lexical item) and the "emotive meaning", and between the second (conceptual) dimension and the "descriptive meaning". They jointly constitute what Kecskes refers to as "coresense", namely, "a summary of the most familiar, regular, typical, and (generally, but not always) frequent uses of a word [which] reflects the history of use of the word and is the common core information that was called public context $[\ldots]$, usually shared by members of a speech community" (2013, p. 141).

This account of the connotative or rather contextual (parole) nature of emotive meaning leads to the problem of explaining the mechanisms underlying how it is generated and stabilized, namely how a context or a set of contexts can modify or introduce and fix culturally a connotative content. A possible explanation can be found in Ducrot's notion of topos. According to Ducrot, an utterance can be described as a bundle of topoi, namely argumentative connections representing instructions such as "uttering $x$, the conclusion $y$ is supported" (Ducrot 1979; Anscombre and Ducrot 1983). As a consequence, the meaning of words can be described as not starting from a previous knowledge of reality (their "descriptive meaning") but considering their discursive (argumentative) potential (Ducrot 1984; Ducrot 1993). Such topoi, or argumentative contexts, are considered by Ducrot as presuppositions; they are characterized by an illocutionary act of presupposition (Anscombre and Ducrot 1983, p. 49). 
The theory of topoi can explain the heuristic judgments that emotive words trigger. For example, we can consider some of the cases illustrated in Section 2, above. In Case 1, by referring to journalists as "liars", Trump automatically triggers the judgment that journalists are despicable and should not be trusted, based on the heuristic or topos that "if someone is a liar, he is untrustworthy and a contemptible person." Similarly, "behemoth" (Case 2) or "dumping ground" (Case 3) trigger automatic negative conclusions ("South Korea and Germany are dangerous as they want to devour other countries"; "The US is being besmeared by migrants"). In Case 5, the public or the military are described as "geniuses" (if they accept the proposition that the media are frequently dishonest) or "incredible", and since both terms semantically encode the concept of "exceptionality", they lead to the conclusion that "they should be approved of", one of the crucial components of the emotion of admiration, as, if someone has an exceptional skill or performs exceptional actions, he should be respected or approved of.

The theory of topoi and the different strategies of use and mischievous use of emotive words point out the complex relationship between the pragmatic phenomenon of presupposition and "emotive meaning". Utterances can have presuppositions that can be of different type (Abrusán 2011; Abrusán 2010), and which can be generated by lexical triggers or syntactic constructions (Levinson 1983, pp. 203-212). Emotive words can be used to manipulate presuppositions in two ways. Through persuasive definitions, "sortal" presuppositions can be triggered: the speaker implicitly redefines a term, leading the interlocutor to considering as true some propositions that he or she has not accepted - or could not accept. For example, in using the emotive words mentioned in Case 1 or Case 5, Trump takes for granted that journalists have said something false, that understanding the alleged media inaccuracies or "dishonesty" is an exceptional capacity, etc. In contrast, the recontextualization of an emotive word to support a conclusion that is not commonly backed by the use of such a word involves the distinct pragmatic strategy of taking for granted a conditional (topos) that is not commonly accepted. For example, in Case 6, Trump's use of "politically correct" in the argument, "There is no time for political correctness, as this country is in big trouble" presupposes that "if someone is politically correct, then 
he or she is wasting time and not addressing the real problems." This presupposition is reinforced by another presuppositional strategy. When Trump claims that "The big problem this country has is being politically correct", he takes for granted that "being politically correct" is a problem, and that US politicians are politically correct.

A quasi-definition can be used for taking for granted propositions (including conditionals) that are not shared, introducing new commitments for the interlocutors (Macagno and Walton 2017, chap. 4) through an act of presupposition (Macagno 2015; Macagno and Walton 2014; Macagno 2012). On this perspective, persuasive definitions and quasi-definitions can be regarded as two distinct tactics for modifying the interlocutors' commitments without providing the necessary reasons.

\section{Conclusion}

The contemporary debate on slurs and emotive words developed in linguistics and pragmatics (Nunberg 2017; Hom 2010) has underscored how the emotive effects resulting from the use of pejoratives or more generally "emotive words" is quite stable across contextscharacteristic that led some scholars to include such meaning into the encoded meaning of these terms. This paper addresses the problem of analyzing the stability of the emotive meaning of ethical terms and more importantly the possibility of modifying and manipulating it. Building on Stevenson's theory, our proposal is to explain emotive meaning as potentiality: the use of emotive words in an utterance triggers a set of inferences leading to a value judgment that can be the basis of an emotional response. The problem was to account for the notion of potentiality, namely, to explain it to make the vague concept of "emotive meaning" representable in an objective way.

The route from the use of an emotive word to the value judgment necessary for the emotive response was described as a chain of classificatory and practical inferences, which can be critically evaluated using argumentation schemes. The emotions that may result from them were shown to provide inferential shortcuts through an automatic route that prevents the critical assessment of the variables involved in each inferential step. 
The relative stability of emotive meaning was explained through the linguistic phenomenon of connotation. It has been argued that emotive meaning can be crafted by means of quasi-definitions, namely recontextualizations in which a specific term is used as a reason for evaluative conclusions triggering or suggesting emotions. This phenomenon involves the act of taking for granted crucial and often unaccepted premises warranting value judgments, manipulating in this latter case the hearer's commitments. The repeated use of the quasi-defined term in similar contexts reinforces the association between the word and the emotion or the value judgment (Kecskes 2013, p. 135; Mey 2006).

The advantages of this approach are both theoretical and empirical. The phenomenon of emotive meaning, which, in linguistics, is mostly addressed either in terms of semantic meaning or contextdependent inferences, is explained in terms of implicit arguments. Emotive meaning can be thus represented and "objectified" in terms of premises and a conclusion that can be evaluated and discussed. The explanation of the stability and the stabilization of emotive meaning in terms of connotation accounts for the possibility of modifying it through quasi-definitions. Connotation, represented as the topoi more frequently associated with the use of a term, can be measured through the tools of corpus linguistics, showing the most frequent contexts of use and co-occurrences of a specific term (for an application of this method, see Macagno, "How can metaphors communicate arguments?", submitted for publication).

This account of emotive meaning has clear limitations. First, it is focused on one very specific dimension of emotive communication (Caffi and Janney 1994), namely, the tendency of some words to be used for eliciting emotional reactions. This paper concerns the problem of explaining how this tendency works and how it can be developed in strategic communication. However, the relative stability of that type of word tendency needs to be considered within the actual unit of analysis, which is the emotional utterance, and the corresponding theoretical framework, which is essentially pragmatic, as centered on the prototypical uses of a word. The second limitation concerns the relationship between inferences, evaluative conclusions, and emotions. In this paper we have presented the inferential mechanism as the potential trigger of emotions; however, we have 
stressed that the evaluative conclusion provides only one of the conditions for an emotion to be aroused. While the type of conclusion can be predicted based on the analysis of the most frequent contexts of use of a word, the emotive reaction depends on factors that go beyond the methods at our disposal. In this sense, our analysis is confined to the boundaries of the aspect of emotions that can be somehow explained through the tools of argumentation theory and linguistics.

Acknowledgments: The authors would like to thank Maria Grazia Rossi for her fruitful insights and comments on this paper and the ideas that she shared and discussed with us, which led to the drafting of this article. This work was supported by the Fundação para a Ciência e a Tecnologia (research grants no. SFRH/BPD/115073/2016, PTDC/FER-FIL/28278/2017, and PTDC/MHC-FIL/0521/2014). Douglas Walton would like to thank the Social Sciences and Humanities Research Council of Canada for Insight Grant 435-2012-0104.

\section{References}

Abrusán, Márta. 2010. Triggering verbal presuppositions. In Semantics and linguistic theory, eds. Nan Li and David Lutz, 684-701. Ithaca, NY: CLC Publications.

Abrusán, Márta. 2011. Predicting the presuppositions of soft triggers. Linguistics and Philosophy 34(6): 491-535. doi:10.1007/s10988-0129108-y

Anscombre, Jean-Claude and Oswald Ducrot. 1983. L'argumentation dans la langue. Bruxelles, Belgium: Pierre Mardaga.

Aristotle. 1991a. Topics. In The complete works of Aristotle, vol. I, ed. Jonathan Barnes. Princeton, NJ: Princeton University Press.

Aristotle. 1991b. Rhetoric. In The complete works of Aristotle, vol. II, ed. Jonathan Barnes. Princeton, NJ: Princeton University Press.

Arnauld, Antoine and Pierre Nicole. 1996. Logic or the art of thinking, ed. Jill Vance Buroker. Cambridge, UK: Cambridge University Press. 
Ben-Ze'ev, Aaron. 2000. The subtlety of emotions. Cambridge, MA: MIT Press.

Bernstein, Richard. 1990. The rising hegemony of the politically correct. New York Times 28 October 1990. URL accessed 31 May 2018: https://www.nytimes.com/1990/10/28/weekinreview/ideas-trends-therising-hegemony-of-the-politically-correct.html

Bianchi, Claudia. 2018. Perspectives and slurs. In Beyond semantics and pragmatics, ed. Gerhard Preyer, 187-198. Oxford, UK: Oxford University Press.

Blakemore, Diane. 2015. Slurs and expletives: A case against a general account of expressive meaning. Language Sciences 52: 22-35. doi:10.1016/j.langsci.2014.06.018

Blanchette, Isabelle and Anne Richards. 2004. Reasoning about emotional and neutral materials-Is logic affected by emotion? Psychological Science 15(11): 745-752. doi:10.1111/j.0956-7976.2004.00751.x

Bump, Philip. 2015. How 'politically correct' moved from Commies to culture and back into politics. The Washington Post, 17 December 2015. URL accessed 31 May 2018: https://www.washingtonpost.com/news/the-fix/wp/2015/12/17/the-interesting-evolution-ofpolitical-correctness/?utm_term $=.38 \mathrm{cf} 66 \mathrm{c} 867 \mathrm{ed}$

Caffi, Claudia and Richard Janney. 1994. Toward a pragmatics of emotive communication. Journal of Pragmatics 22(3-4): 325-373. doi:10.1016/0378-2166(94)90115-5

Cato, Allison, Bruce Crosson, Didem Gökçay, David Soltysik, Christina Wierenga, Kaundinya Gopinath, Nathan Himes, et al. 2004. Processing words with emotional connotation: An FMRI study of time course and laterality. Journal of Cognitive Neuroscience 16(2): 167-177. doi:10.1162/089892904322984481

Chen, Serena and Shelly Chaiken. 1999. The heuristic-systematic model in its broader context. In Dual-process theories in social psychology, eds. Shelly Chaiken and Yaacov Trope, 73-96. New York, NY: Guilford Press. 
Clark, Herbert. 1996. Using language. Cambridge, UK: Cambridge University Press.

Clore, Gerald and Karen Gasper. 2000. Feeling is believing: Some affective influences on belief. In Emotions and beliefs: How feelings influence thoughts, eds. Nico Frijda, Antony Manstead and Sacha Bem, 0-44. Cambridge, UK: Cambridge University Press.

Croom, Adam. 2011. Slurs. Language Sciences 33(3): 343-358. doi:10.1016/j.langsci.2010.11.005

Croom, Adam. 2014. The semantics of slurs: A refutation of pure expressivism. Language Sciences 41: 227-242. doi:10.1016/j.langsci.2013.07.003

Cruse, Alan. 1992. Antonymy revisited: Some thoughts on the relationship between words and concepts. In Frames, Fields, and Contrasts, eds. Adrienne Lehrer and Eva Feder Kittay, 289-306. Hillsdale, NJ: Lawrence Erlbaum Associates.

Damasio, Antonio. 1994. Descartes' error: Emotion, reason, and the human brain. New York, NY: Avon Books.

Doerksen, Sharon and Arthur Shimamura. 2001. Source memory enhancement for emotional words. Emotion (Washington, D.C.) 1(1): 5-11. doi:10.1037/1528-3542.1.1.5

Druckman, James. 2002. The implications of framing effects for citizen competence. Political Behavior 23(3): 225-256. doi:10.1023/A:1015006907312

Ducrot, Oswald. 1979. Les lois de discours. Langue Française 42: 21-33. doi:10.3406/lfr.1979.6152

Ducrot, Oswald. 1984. Le dire et le dit. Paris, France: Minuit.

Ducrot, Oswald. 1993. Les topoi dans la "Théorie de l'argumentation dans la langue". In Lieux communs, topoi, stéréotypes, ed. Christian Plantin, 233-248. Paris, France: Kimé. 
Elster, Jon. 1999. Alchemies of the mind: rationality and the emotions. New York, NY: Cambridge University Press.

Entman, Robert M. 1993. Framing: Toward clarification of a fractured paradigm. Journal of Communication 43(4): 51-58. doi:10.1111/j.1460-2466.1993.tb01304.x

Federal News Service. 2016. Transcript of Donald Trump's Dec. 30 speech in Hilton Head, S.C. URL accessed 31 May 2018: http://www.kansascity.com/news/local/news-columns-blogs/the-buzz/article55604115.html

Frijda, Nico. 1988. The laws of emotion. American Psychologist 43(5): 349-358.

Frijda, Nico and Batja Mesquita. 1998. The analysis of emotions. In What develops in emotional development?, eds. Michael Mascolo and Sharon Griffin, 273-295. New York, NY: Plenum Press.

Frijda, Nico and Batja Mesquita. 2000. Beliefs through emotions. In Emotions and beliefs: How feelings influence thoughts, eds. Nico Frijda, Anthony Manstead and Sacha Bem , 45-77. Cambridge, UK: Cambridge University Press.

Gambino, Lauren. 2015. Donald Trump retweets Megyn Kelly 'bimbo’ jab as women react to insults. The Guardian, 7 August 2015. URL accessed 31 May 2018: https://www.theguardian.com/usnews/2015/aug/07/donald-trump-megyn-kelly-bimbo-women-republican-debate

Garza-Cuarón, Beatriz. 1991. Connotation and meaning. Berlin, Germany: Walter de Gruyter.

Giora, Rachel. 2003. On our mind: Salience, context, and figurative language. Oxford, UK: Oxford University Press.

Giora, Rachel. 2008. Is metaphor unique? In The Cambridge handbook of metaphor and thought, ed. Raymond Gibbs, 143-160. New York: Cambridge University Press. 
Greene, Joshua and Jonathan Haidt. 2002. How (and where) does moral judgment work? Trends in Cognitive Sciences 6(12): 517-523. doi:10.1016/S1364-6613(02)02011-9

Gregoire, Carolyn. 2016. A surprising thing happens when presidential candidates use emotional language. The Huffington Post, 21 March 2016. URL accessed 31 May 2018: http://www.huffingtonpost.com/entry/donald-trump-emotional-inflammatory-language_us_56e84b60e4b0860f99da8d3e?utm_hp_ref=science

Hamblin, Charles Leonard. 1970. Fallacies. London: Methuen.

Hampson, Rick. 2016. Donald Trump's attacks on the news media: A notso-short history. USA Today, 10 March 2016. URL accessed 31 May 2018: http://www.usatoday.com/story/news/politics/onpolitics/2016/03/10/donald-trump-versus-the-media/81602878/

Hartmann, Margaret. 2016. Trump Explains why Rubio is 'Weak like a baby,' and other hits from his 95-minute rant. The New York Magazine, 13 November 2015. URL accessed 31 May 2018: http://nymag.com/daily/intelligencer/2015/11/best-of-trumps-95-minute-rant-compilation.html

Hjelmslev, Louis. 1969. Prolegomena to a theory of language. Madison, WI: University of Wisconsin Press.

Hom, Christopher. 2008. The semantics of racial epithets. The Journal of Philosophy 105(8): 416-440. doi:0.2307/20620116

Hom, Christopher. 2010. Pejoratives. Philosophy Compass 5(2): 164-185. doi:10.1111/j.1747-9991.2009.00274.x

Jeshion, Robin. 2013. Slurs and stereotypes. Analytic Philosophy 54(3): 314-329. doi:10.1111/phib.12021

Kahneman, Daniel. 2003. A perspective on judgment and choice. American Psychologist 58(9): 697-720. doi:10.1037/0003066X.58.9.697 
Kecskes, Istvan. 2003. Situation-bound utterances in L1 and L2. Berlin, Germany, and New York, NY: Mouton de Gruyter.

Kecskes, Istvan. 2008. Dueling contexts: A dynamic model of meaning. Journal of Pragmatics 40(3): 385-406. doi:10.1016/j.pragma.2007.12.004

Kecskes, Istvan. 2013. Intercultural pragmatics. Oxford, UK: Oxford University Press.

Kecskes, Istvan and Fenghui Zhang. 2009. Activating, seeking, and creating common ground: A socio-cognitive approach. Pragmatics \& Cognition 17(2): 331-355. doi:10.1075/pc.17.2.06kec

Kecskes, Istvan and Fenghui Zhang. 2013. On the dynamic relations between common ground and presupposition. In Perspectives in pragmatics, philosophy \& psychology, eds. Alessandro Capone, Franco Lo Piparo and Marco Carapezza, 375-395. Cham, Switzerland: Springer.

Keltner, Dacher and Jennifer Lerner. 2010. Emotion. In Handbook of social psychology, eds. Susan Fiske, Daniel Gilbert and Gardner Lindzey, 317-352. New York, NY: John Wiley \& Sons.

Kerbrat-Orecchioni, Catherine. 1977. La connotation. Lyon, France: Presses Universitaires de Lyon.

Kovecses, Zoltan. 2015. Where metaphors come from: Reconsidering context in metaphor. Oxford, UK: Oxford University Pres.

Lerner, Jennifer, Ye Li, Piercarlo Valdesolo and Karim Kassam. 2015. Emotion and decision making. Annual Review of Psychology 66: 799823. doi:10.1146/annurev-psych-010213-115043

Levinson, Stephen. 1983. Pragmatics. Cambridge, UK: Cambridge University Press. 
Loewenstein, George and Jennifer Lerner. 2003. The role of affect in decision making. In Handbook of affective science, ed. Richard Davidson, Klaus Scherer and Hill Goldsmith, 619-642. Oxford, UK: Oxford University Press.

Macagno, Fabrizio. 2012. Reconstructing and assessing the conditions of meaningfulness: An argumentative approach to presupposition. In Inside arguments: Logic and the study of argumentation, ed. Henrique Ribeiro, 247-268. Newcastle upon Tyne, UK: Cambridge Scholars Publishing.

Macagno, Fabrizio. 2015. Presupposition as argumentative reasoning. In Interdisciplinary studies in pragmatics, culture and society, eds. Alessandro Capone and Jacob Mey, 465-487. Cham, Switzerland: Springer.

Macagno, Fabrizio and Douglas Walton. 2008. The argumentative structure of persuasive definitions. Ethical Theory and Moral Practice 11(5): 525-549. doi:10.1007/s10677-008-9119-5

Macagno, Fabrizio and Douglas Walton. 2010. What we hide in words: Emotive words and persuasive definitions. Journal of Pragmatics 42(7): 1997-2013. doi:10.1016/j.pragma.2009.12.003

Macagno, Fabrizio and Douglas Walton. 2014. Emotive language in argumentation. New York, NY: Cambridge University Press.

Macagno, Fabrizio and Douglas Walton. 2017. Interpreting straw man argumentation: The pragmatics of quotation and reporting. Amsterdam, Netherlands: Springer.

Macagno, Fabrizio and Douglas Walton. 2018. Practical reasoning arguments: A modular approach. Argumentation 32(4): 519-547. doi:10.1007/s10503-018-9450-5

Mey, Jacob. 2006. Pragmatic acts. In Encyclopedia of language and linguistics, ed. Keith Brown, 5-11. New York, NY: Elsevier.

Molino, Jean. 1971. La connotation. La Linguistique 7(1): 5-30. 
Neuman, Scott. 2015. Trump lashes out at McCain: 'I like people who weren't captured.' NPR, 8 July 2015. URL accessed 31 May 2018: http://www.npr.org/sections/thetwoway/2015/07/18/424169549/trump-lashes-out-at-mccain-i-like-people-who-werent-captured

Nunberg, Geoffrey. 2017. The social life of slurs. In New work on speech acts, eds. Daniel Fogal, Daniel Harris and Matt Moss. Oxford, UK: Oxford University Press.

Perelman, Chaim and Lucie Olbrechts-Tyteca. 1951. Act and person in argument. Ethics 61(4): 251-269. doi:10.1086/290789

Petty, Richard and John Cacioppo. 1986. The elaboration likelihood model of persuasion. Advances in Experimental Social Psychology 19: 123205. doi:10.1016/S0065-2601(08)60214-2

Pugmire, David. 1998. Rediscovering emotion. Edinburgh, UK: Edinburgh University Press.

Quintilianus, Marcus Fabius. 1996. Institutio Oratoria, ed. Harold Edgeworth Butler. Cambridge, MA: Harvard University Press.

@ realDonaldTrump. 2015. So many "politically correct" fools in our country. We have to all get back to work and stop wasting time and energy on nonsense! Twitter, 8 Aug 2015, 5:29 AM. URL accessed 20 August 2019: https://twitter.com/realdonaldtrump/status/629992743788523520

Ritchie, David. 2006. Context and connection in metaphor. New York, NY: Palgrave.

Samet, Jerry and Roger Schank. 1984. Coherence and connectivity. Linguistics and philosophy 7(1): 57-82. doi:10.1007/BF00627475

Smith, Craig and Richard Lazarus. 1990. Emotion and adaptation. In Handbook of personality: Theory \& research, ed. Lawrence Pervin, 609-637. New York, NY: Guilford Press. 
Solomon, Robert. 2003. Not passion's slave: Emotions and choice. New York, NY: Oxford University Press.

Sousa, Ronald de. 1987. The rationality of emotion. Cambridge, MA: MIT Press.

Stevenson, Charles. 1937. The emotive meaning of ethical terms. Mind XLVI(181): 14-31. doi:10.1093/mind/XLVI.181.14

Stevenson, Charles. 1938a. Persuasive definitions. Mind 47: 331-350. doi:10.1093/mind/xlvii.187.331

Stevenson, Charles. 1938b. Ethical judgments and avoidability. Mind XLVII(185): 45-57. doi:10.1093/mind/XLVII.185.45

Stevenson, Charles. 1944. Ethics and language. New Haven: Yale University Press.

Stokols, Eli. 2016. Trump's loaded words fuel campaign freefall. Politico, 8 September 16. URL accessed 31 May 2018: http://www.politico.com/story/2016/08/donald-trump-campaign-statements-226840

Tumulty, Karen and Jenna Johnson. 2016. Why Trump may be winning the war on 'political correctness'. The Washington Post, 4 January 2016. URL accessed 31 May 2018: https://www.washingtonpost.com/politics/why-trump-may-be-winning-the-war-on-political-correctness/2016/01/04/098cf832-afda-11e5-b7111998289ffcea_story.html?utm_term=.0f77f4556e35

Vendler, Zeno. 1963. The grammar of goodness. The Philosophical Review 72(4): 446-465.

Walton, Douglas and Erik Krabbe. 1995. Commitment in dialogue. Albany, NY: State University of New York Press.

Walton, Douglas, Christopher Reed and Fabrizio Macagno. 2008. Argumentation schemes. New York, NY: Cambridge University Press. 
Wildermuth, John. 2016. Trump's loaded language a reminder of words' power. San Francisco Chronicle, 9 August 2016. URL accessed 31 May 2018: http://www.sfchronicle.com/politics/article/Trump-sloaded-language-a-reminder-of-words-9133067.php

Wright, Georg von. 1963a. The varieties of goodness. London, UK: Routledge.

Wright, Georg von. 1963b. Practical inference. The Philosophical Review 72(2): 159-179. 